\title{
THE HISTORICAL ORIGINS OF THE SANCTION OF IMPRISONMENT FOR SERIOUS CRIME
}

\author{
JOHN H. LANGBEIN*
}

$\mathrm{T}$ HE movement for the abolition of capital punishment is righty associated with the writers of the Enlightenment, especially Beccaria, whose enormously influential tract appeared in 1764. Perhaps because the abolitionists drew so much attention to the gore of the capital sanctions of the eighteenth century, it has seldom been realized that capital punishment was already in a deep decline in the age of Beccaria and Voltaire. Writing to Voltaire in 1777, Frederick the Great boasted that in the whole Prussian realm executions had been occurring at the rate of only 14 or 15 per year. ${ }^{1}$ When John Howard visited Bremen in 1778 he discovered that "[ $\mathrm{t}$ ] here has been no execution in this city for twenty-six years."

The abolition movement that we associate with Beccaria and Voltaire ${ }^{3}$ was a second-stage affair. Indeed, it had to be. For abolition presupposes the existence of a workable alternative for the punishment of serious crime. By the time of the American Revolution, the sanction of imprisonment for serious crime was in use throughout Europe, and England had developed a near equivalent. Although it is commonly said that " $[t]$ he history of imprisonment has often been told,"4 Americans have not listened with much care. The claim is incessantly made that "[p]risons . . . are a pervasive American export, like tobacco in their international acceptance and perhaps

* Professor of Law, University of Chicago.

(C) Copyright 1976 by John H. Langbein. This article is based on Chapter 2 of a forthcoming book, The Law of Torture in the Ancien Régime (1977). Quotations from foreign language sources are the author's translations. In quotations from English sources/the spelling has been modernized and Americanized; abbreviated words have been written out; capitalization, italicization, and punctuation are original unless otherwise indicated. References supplied by Paul Bamford, Stanley Katz, Julius Kirshner, Donald McCloskey, Norval Morris, and Lawrence Towner are gratefully acknowledged.

1 Eberhard Schmidt, Die Kriminalpolitik Preussens unter Friedrich Wilhelm I. und Friedrich II., at 65-66 (1914).

2 John Howard, The State of the Prisons 63 (Everyman's Lib. ed. 1929).

3 Voltaire was not in fact an abolitionist. He thought it appropriate to execute the worst offenders, whom he likened to mad dogs. Marcello Maestro, Voltaire and Beccaria as Reformers of Criminal Law 121 (1942).

4 Norval Morris, The Future of Imprisonment 3 (1974). 
also in their adverse consequences." the nineteenth-century American prisons, but the essentials were long established in Europe. This article draws upon the rich but scattered Continental scholarship in order to describe the origins of imprisonment in Europe and to relate it to the parallel developments that had taken place in the common law by the eve of American independence.

\section{The Blood Sanctions}

"The one punishment," said Maitland, "that can easily be inflicted by a state which has no apparatus of prisons and penitentiaries is death." Another class of sanctions as easy to administer as death is physical mutilation of the culprit. These punishments, death and maiming, were the ordinary penalties for serious crime in the Western legal systems in the later Middle Ages.

At about the time that the medieval sanctions were entering their long decline, they were codified in the German Empire in the Constitutio Criminalis Carolina of $1532 .^{7}$ The statute provides a typical assortment of modes of capital punishment. An ordinary murderer or burglar merits hanging in chains or beheading with the sword. A woman who murders her infant is buried alive and impaled, a traitor is drawn and quartered. Other grave offenders may be burned to death, or drowned, or set out to die in agony upon the wheel with their limbs smashed. If the court thinks that the circumstances of the crime merit severer punishment, it may order that the criminal be dragged to the place of execution, and that his flesh be torn with red-hot tongs before he is killed. For less grave offenses the Carolina prescribes afflictive punishments-flogging, pillorying, cutting off the ears, chopping off the fingers, cutting out the tongue-usually accompanied by a sentence of banishment. The Carolina's catalog of sanctions for serious crime exemplifies not only German but general European practice of the age. ${ }^{8}$

5 Id. at 5. See also note 158 infra.

6 2 Frederick Pollock \& Frederic W. Maitland, The History of English Law before the Time of Edward I, at 452 (2d ed., Cambridge, 1898).

7 Constitutio Criminalis Carolina Articles 190-198 collect the sanctions. For particular offenses, see Articles 124 (treason), 131 (child murder), 137 (murder), 159 (burglary). Articles 176 and 195 contemplate a scheme of perpetual preventive detention of someone who is found dangerous and who lacks surety; it seems to have had no practical currency. German editions of the Carolina are discussed in John H. Langbein, Prosecuting Crime in the Renaissance: England, Germany, France 259-60 (1974); see id. at 261-308 for a translation of most of the statute.

82 Hermann Conrad, Deutsche Rechtsgeschichte 410 (1966); cf. 1 Daniel Jousse, Traité de la justice criminelle de France 36-73 (Paris, 1771); Bernard Schnapper, La répression pénale au XVIe siècle: L'exemple du Parlement de Bordeaux: 1510-1565, in 8 Recueil de mémoires et travaux publié par la société d'histoire du droit et des institu- 
The first comprehensive criminal code that completely abolished capital punishment was the Leopoldina ${ }^{9}$ of 1786 , promulgated by the future German (Austrian) Emperor Leopold II for the state of Tuscany, the region around Florence and Pisa which was then a Hapsburg duchy. In the Leopoldina a few of the punishments are familiar-flogging, pillorying, and banishment. But the Carolina's blood sanctions have disappeared. The principal sanction that has displaced capital punishment is imprisonment. (We shall be using the word "imprisonment" in the sense of the German Freiheitsstrafe to mean confinement anywhere, not just in prison, and to include both confinement simple and confinement subject to further conditions such as hard labor.) In the Leopoldina confinement, sometimes at hard labor for terms up to life, has become the exclusive sanction for serious crime, ${ }^{10}$ whereas two and $\mathbf{a}$ half centuries before in the Carolina death and maiming had been equally exclusive.

The substitution of various forms of imprisonment for the sanctions of the medieval law began in the sixteenth and seventeenth centuries both on the Continent and in England. By the middle of the eighteenth century, when the first demands for total abolition of capital punishment were made, the death penalty had everywhere ceased to be the exclusive punishment for

tions des anciens pays de droit écrit 1, 28-34; 1 Sir James Fitzjames Stephen, A History of the Criminal Law of England 457ff, esp. 475-78, 489-90 (London, 1883); Sir Leon Radzinowicz, A History of English Criminal Law and Its Administration 206ff (1948). See generally the remarkable compilation in $1 \mathrm{Jacob}$ Döpler, Theatrum poenarum . . . Oder Schau-Platz derer Leibes und Lebens-Straffen (Sondershausen, 1693).

${ }^{9}$ Riforma della legislazione criminale del 30 novembre del 1786 (Florence, 1786), described as a "bibliographic rarity" in Stanislaw Salmonowicz, Leopoldina: Il codice penale toscano dell'anno 1786, 13 Revista Italiana per le Scienze Giuridiche (3d ser.) 173, 179 n.16 (1969) (citing Italian and French editions). The Italian edition was reprinted in England together with an anonymous English translation as Edict of the Grand Duke of Tuscany for the Reform of Criminal Law in His Dominions (Warrington, 1789). A German edition of 1787 is cited in 2 Conrad, supra note 8 , at 449 . Article 55 catalogs the sanctions.

10 Leopoldina, supra note 9, Articles 51, 53. A few weeks later Leopold's brother, the Emperor Joseph II, promulgated a criminal code for Austria that preserved the death penalty only for martial law and confirmed the substitution of imprisonment as the ultimate penal sanction: Patent vom 13ten Januar 1787, für alle Länder $\$ \$ 20,21$, in Joseph des Zweiten römischen Kaisers Gesetze und Verfassungen im Justiz-Fache 1786-1787, at 7, 12 (Vienna, 1817). An anonymous contemporary English translation appeared in the same year, from which (with one correction shown in square brackets) we reprint the two sections:

\$ 20. No person shall be punished with death, except in cases in which it shall be pronounced according to law in a court-martial. It is resolved that in case of such court-martial, hanging shall be the only punishment by death that can be inflicted. ...

\& 21. The other punishments are [imprisonment in chains], imprisonment with hard labor on the public works, imprisonment only, corporal punishment with whip, rod, or stick, and the pillory.

The Emperor's New Code of Criminal Laws: Published at Vienna, the 15th [sic] of January, 1787: Translated from the German by an Officer 10 (London, 1787). 
serious crime. The abolition movement is much celebrated. This article examines the development that made it possible.

\section{MEDIEVAL IMPRISONMENT}

Imprisonment had an important place in European criminal procedure in the Middle Ages, but not as a sanction. The rule of the ius commune, constantly repeated by the jurists and codified in statutes like the Carolina, was that prisons were meant to detain and not to punish. ${ }^{11}$ In cases of serious crime the only function that the jurists conceded to imprisonment was pretrial detention, keeping custody of the accused while the court decided whether to acquit him or to convict and punish him with a blood sanction. This "custodial"12 or "preventive"13 imprisonment is distinguished from the other common medieval usage that the jurists approved: "coercive" imprisonment designed to compel someone to take some other procedural step, characteristically the payment of a crown debt or a civil judgment debt. ${ }^{14}$

We are concerned with a third usage, so-called "penal" or "punitive" imprisonment, ${ }^{15}$ confinement as a mode of punishment. Penal imprisonment first appeared in the Middle Ages in the legal system of the church. Ecclesiastical courts did not impose the blood sanctions, which in canon law were deemed inconsistent with the clerical station. Even when ecclesiastical proceedings led to a death sentence, as in the heresy inquisitions, the church courts "relaxed" the condemned heretic to the secular authorities for the imposition of capital punishment. ${ }^{16}$ Incapable of employing the ordinary secular sanctions of the day, the church had a considerable incentive to develop an alternative. The church also had the elementary administrative capacity that imprisonment requires, to construct and maintain places of confinement and to care for those incarcerated. ${ }^{17}$

11 Constitutio Criminalis Carolina Articles 11, 218, translated in Langbein, supra note 7 , at $270,307$.

12 Ralph B. Pugh, Imprisonment in Medieval England 3-5 (1968). The principal English criminal trial court, that of gaol (jail) delivery, took its name from the gaols which held prisoners until trial.

13 Annik Porteau-Bitker, L'emprisonnement dans le droit laïque du Moyen Age, 46 Revue historique de droit français et étranger 211 (1968); Roger Grand, La prison et la notion d'emprisonnement dans l'ancien droit, 19/20 Revue historique de droit français et étranger 58, 58-59 (1940-41).

14 Pugh, supra note 12 , at $5 \mathrm{ff}$; Porteau-Bitker, supra note 13, at 211; Grand, supra note 13, at 58-59; 1 Gotthold Bohne, Die Freiheitsstrafe in den italienischen Stadtrechten des 12.-16. Jahrhunderts 34ff. (1922, 1925).

16 Pugh, supra note 12, at 16ff.; Porteau-Bitker, supra note 13, at 211; Grand, supra note 13 , at $58-59 ; 1$ Bohne, supra note 14 , at $51 \mathrm{ff}$.

161 Henry Charles Lea, A History of the Inquisition of the Middle Ages 534 (New York, 1888).

171 Bohne, supra note 14, at $232 \mathrm{ff}$.; Porteau-Bitker, supra note 13, at 390-91; Pugh, supra note 12 , at 17 ; 1 Lea, supra note 16 , at 484-94. 
Penal imprisonment did enter the secular legal systems in the late Middle Ages, but not in place of the blood sanctions for serious crimes. Rather, it was imposed as a sanction for petty crime: often as a "surrogate penalty"18 for a petty offender who was unable to pay a fine, sometimes as a "collateral penalty"19 in addition to a fine. In Italy, France, Germany, and England the sources evidence growing use of short-term imprisonment as a sanction for economic and moral regulation from the fourteenth century onward. ${ }^{20}$ When the Belgian jurist Damhouder summarized the practice of the midsixteenth century, it was still true that of the "several sorts of prisons" only those of the church were being used to punish serious crime. The secular prisons existed to guard serious offenders until their trials. Only for petty crime were the secular courts sentencing culprits to brief prison terms, occasionally on a diet of bread and water. ${ }^{21}$

\section{The Galley Sentence}

Over the course of the sixteenth and seventeenth centuries the foundations were laid at opposite ends of Europe for a new penal system for serious crime. The Mediterranean states introduced the galley sentence, and the countries of the North founded the workhouse. Both institutions arose to serve social purposes remote from the ordinary criminal law. Nevertheless, they converged under the ancien régime to form the prison system that displaced the blood sanctions from European law.

"The galley sentence arose not from the needs of criminal justice, rather its origin is most closely connected with the development of the medieval fleets of the naval powers of southern Europe."22 Although sailing ships were coming into use by the end of the Middle Ages, galleys rowed by oarsmen continued to be important military vessels in the Mediterranean into the eighteenth century. Because galleys were highly maneuverable, they were more suitable for Mediterranean coastal waters than were the ocean-

181 Bohne, supra note 14, at 57-58; Porteau-Bitker, supra note 13, at 402-03.

19 Porteau-Bitker, supra note 13, at 396-97.

201 Bohne, supra note 14, at 54-67, 80-90, 98ff.; Eberhard Schmidt, Einführung in die Geschichte der deutschen Strafrechtspflege 64-65, 193-94 (3d ed., 1965); PorteauBitker, supra note 13, at $395 \mathrm{ff}$; Pugh, supra note 12 , at $26 \mathrm{ff}$.

21 Joost Damhouder, Practique judiciaire es [sic] causes criminelles, ch. 16, at 16 $16^{\mathrm{V}-17}$ (Antwerp, 1564 ed.) [hereafter cited as Damhouder]. The work was first published under the title Praxis rerum criminalium in Louvain in 1554; it had enormous authority and went through over 30 editions in Latin, French, Dutch and German, the last in 1693. See Rene Dekkers, Bibliotheca Belgica Juridica 44 (1951).

22 P. Frauenstädt, Zur Geschichte der Galeerenstrafe in Deutschland, 16 Zeitschrift für die gesamte Strafrechtswissenschaft 518,519 (1896); compare 2 Bohne, supra note 14 , at 302-03. 
going ships of the Atlantic. Unlike wind-powered craft, they could not be becalmed. Not until the eighteenth century did the superior size, speed and firepower of the sailing ships fully overcome the military advantages of the galleys and render them obsolete. ${ }^{23}$

Galleys required several hundred oarsmen rowing in unison. The work was strenuous, dangerous, and severely disciplined. ${ }^{24}$ Because volunteer oarsmen were not in sufficient supply at wages the fleets were willing to pay, the fleets supplemented hirelings with galley slaves, usually Turks and North Africans either captured in war or bought for the purpose. ${ }^{25}$ When these sources became inadequate to staff the growing fleets of the fifteenth and sixteenth centuries, the practice began in the West of forcing condemned criminals to serve as oarsmen. ${ }^{26}$ Convicts whom the state had been eliminating through capital punishment were now regarded as a potential resource. From Spain, ${ }^{27}$ Italy, ${ }^{28}$ and France ${ }^{29}$ the galley sentence spread to the North. It is reported in the Netherlands ${ }^{30}$ in the 1520 s and in Belgium ${ }^{31}$ and Austria $^{32}$ in the 1550 s.

Condemned criminals were at first obtained for the galleys by exercise of executive commutation power. In France, lettres royales commissioned "galley captains to procure oarsmen among the prisoners condemned to death or to another major bodily punishment."33 In Belgium, then the Spanish

23 Paul W. Bamford, Fighting Ships and Prisons: The Mediterranean Galleys of France in the Age of Louis XIV, at 12-18, 272ff. (1973).

24 Described in the classic work by Paul Masson, Les galères de France, 20 Annales de la faculté des lettres d'Aix 7, 72ff. (1937).

25 Bamford, supra note 23 , at $138 \mathrm{ff}$.

26 of course the use of captives in the galleys had been known in antiquity, and may have been a more or less continuous practice in the Eastern Mediterranean into the Renaissance. See Masson, supra note 24, at 8-10.

27 See I. A. A. Thompson, A Map of Crime in Sixteenth-Century Spain, 21 Economic History Review (2d ser.) 244 (1968).

282 Bohne, supra note 14, at 302, 320ff.

29 The French galley fleet began to be built up in the fifteenth century when Provence was joined to the monarchy and France became involved in the Italian wars. Masson, supra note 24 , at 15 . The use of convict labor on the galleys was suggested as early as 1443 , id. at 80 . As early as 1490 instructions were issued in the name of the king to the royal and seignorial courts to spare capital convicts for the galleys, and to sentence vagabonds there as well. $I d$. at 83 ; cf. infra note 50 . Schnapper found the galley sentence in use in the Parlement of Bordeaux in the 1520s. Schnapper, supra note 8, at 33.

30 Thorsten Sellin, Pioneering in Penology: The Amsterdam Houses of Correction in the Sixteenth and Seventeenth Centuries 7-8 (1944).

31 Damhouder added a lengthy chapter to his treatise to take account of the "nouvelle punition criminelle" in Belgian practice. Damhouder, ch. 151, at 203v. The earliest ordinance he cites is from 1554. Id., ch. 151, at 204. Elsewhere it is said that convicts were being used on galleys at Antwerp in the middle of the fifteenth century. Louis Stroobant, Notes sur le système pénal des villes flamandes du XVe au XVII' siècle 57 (Malines, 1897).

32 Frauenstädt, supra note 22, at 522 .

33 Schnapper, supra note 8, at 33; see supra note 29. 
Netherlands, Charles V and Philip II periodically authorized their governor in Brussels to commute capital punishment into sentences to the Spanish galleys. ${ }^{34}$ The Austrian Hapsburgs were delegating their commutation power when they authorized local courts in their German, Austrian and Bohemian lands to remit capital sentences into galley sentences for Philip's fleet. ${ }^{35}$

In France and the other states that made relatively sustained use of the galley sentence, the courts undertook to impose galley sentences directly. ${ }^{36}$ However, the need for oarsmen fluctuated with the fortunes of the fleet. In France, for example, Henry III had to order the courts to cease sending men to the galleys in 1558, whereas in 1602 Henry IV was again demanding galley convicts. ${ }^{37}$ In 1662 Colbert found it necessary to "reestablish" galley sentences for the wars of Louis XIV, imploring the courts to "convert the death penalty into that of the galleys . . ."38 In Austria, which had no fleet of its own, the galley sentence was spasmodically employed for the benefit of allied fleets-in 1556, again in 1570, and variously in the seventeenth century. ${ }^{39}$ After the Austrians acquired Naples in 1707, an imperial patent of 1716 instituted the export of convicts to the Neapolitan fleet. ${ }^{40}$ By 1727 there was a surplus of Austrian convicts in Naples, and in 1728 the courts were ordered to cut back. ${ }^{41}$ Courts in some regions of the Austrian Empire continued to sentence convicts to galley service in Venice until Maria Theresa forbade it in $1762 . .^{42}$

The motivation for the galley sentence was strictly exploitative. There was occasional lip service to reformative values, such as the Austrian King Ferdinand's pronouncement in a patent of 1556 that galley service would give the criminal an opportunity to atone for his misdeeds through hard labor ${ }^{43}$ Damhouder was more honest in calling the galleys worse than death, ${ }^{\mathbf{4 4}}$ and Ferdinand remarked in the Austrian patent of 1556 that since galley service was more feared than execution, changing capital sentences to galley sentences ought not to impair the deterrent force of the criminal law. ${ }^{45}$

34 Damhouder, ch. 151, at 204.

35 Frauenstädt, supra note 22, at 522-24, 539-41.

36 See Schnapper, supra note 8, at 34-35.

37 Ernest Lavisse, Sur les galères du roi, 4 La revue de Paris 225, 236 (1897).

383 Jean-Baptiste Colbert, Lettres instructions et mémoires, pt. 1, at 1 (Pierre Clément ed.) (Paris, 1864); cf. 2 G. B. Depping, Correspondance administrative sous le règne de Louis XIV 879, 880, 940 (Paris, 1851).

39 Frauenstädt, supra note 22, at 522-39.

40 Friedrich von Maasburg, Die Galeerenstrafe in den deutschen und böhmischen Erbländern Oesterreichs 7 (Vienna, 1885).

41 Id. at $10-11$.

42 Id. at 14-15.

43 Frauenstädt, supra note 22, at 524, 540-41.

44 Damhouder, ch. 151, at 2087.

45 Frauenstädt, supra note 22 , at 524, 540-41. 
Ferdinand also ordered that convicts who were physically unfit for galley service should be executed as before. ${ }^{46}$ Humanitarian considerations were equally distant in seventeenth-century France, where the law provided for one class of galley convicts that their ears and noses be cut off and that they be branded with fleurs-de-lis on each cheek before being sent to the galleys for life. ${ }^{47}$ We can imagine what conditions forced Louis XIV to issue a decree $^{48}$ in 1677 complaining that men sentenced to the galleys had been mutilating themselves in order to avoid galley service, and henceforth those who did it would be put to death. ${ }^{49}$

In periods when the need for oarsmen was intense, the authorities cast a very wide net for convicts. Men who merited the death sentence were sent to the galleys for life, lesser offenders were sent to the galleys for terms of years instead of being maimed or banished..$^{50}$ Vagabonds were conscripted..$^{51}$

$46 I d$. at 522,540 .

4719 F. A. Isambert, Decrusy \& Jourdan, Recueil général des anciennes lois françaises depuis l'an 420 jusqu'à la révolution 465 (Paris, 1823-33).

4819 id. at 176.

49 See generally on the conditions of galley life Bamford, supra note 23, at $200 \mathrm{ff}$.

50 For the Spanish Netherlands see the decree of 1561, probably based on one of 1554, authorizing galley sentences of not less than six years for convicts whose offenses do not merit death: Damhouder, ch. 151, at $213^{\%}$. Damhouder explains that these ordinances meant to prevent judges from imposing galley sentences of two, three or four years for such offenders as they had formerly been doing. Id., ch. 151, at 203 ${ }^{\mathrm{v}}-204$. For seventeenthcentury Italian city-state sources substituting galley service for the former sanctions of fine, imprisonment, and corporal punishment for lesser crimes see 2 Bohne, supra note 14, at 321ff.; for eighteenth-century Austria see von Maasburg, supra note 40, at 7, 10.

Schnapper found galley sentences of five and ten years being imposed in the $1520 \mathrm{~s}$ in the Parliament of Bordeaux. Schnapper, supra note 8, at 33-34. By Jousse's day, the sanction of galères à temps was being imposed "for a great number of crimes; as for forgery, repeated petty theft, . . . altering boundary markers, theft from churches, highway robbery, etcetera. It is also used against beggars . . . [and] vagabonds." 1 Jousse, supra note 8, at 61 . Recently published data from the 1748 register of French galley convicts bear out Jousse's account. Of 4000 men, 40 per cent had been sentenced for theft, swindling and forgery; 25 per cent for infractions against the salt and tobacco monopolies, five per cent as vagabonds. André Zysberg, La société des galèriens au milieu de XVIIIe siècle, 30 Annales Economies Sociétés Civilisations 43-49 (1975). Bamford shows that in the seventeenth century convicts sentenced to determinate terms might be kept in galley service much longer. Bamford, supra note 23, at 250-53.

51 The use of so-called vagabonds as galley conscripts is evidenced from the inception of the galley system in the fifteenth century to its demise in the eighteenth century. Damhouder introduces his account of the galley sentence as "that manner of punishment by which worthless people (gens de nulle valeur), vagabonds, living without established reputation or habitation, ... pests of the republic are condemned to naval prisons, vulgarly called galleys ...." Damhouder, ch. 151, at 203". As early as 1456 there appear in the French ordinances lettres de marque complaining of the influx of vagabonds, their dangerousness and their potential for criminality, and authorizing the authorities to punish them summarily, inter alia, by sending them to the galleys. 9 Isambert et al., supra note 47 , at 302-03. On the many shades of meaning and the complex causes of vagabondage, see infra pp. 44-47. 
On the other hand, the galley sentence did not wholly eliminate capital punishment, even when oarsmen were in great demand. The most heinous offenders continued to be subjected to capital punishment, ${ }^{52}$ perhaps for deterrent purposes, perhaps for fear that they might escape from the galleys and return to their former ways.

The development of the galley sentence reflected not only the new needs of the Renaissance state but its new capacities as well. Convicts had to be selected, assembled, provisioned, chained, and marched to the ports. ${ }^{58}$ The flow of convicts had to be adjusted to the fluctuating requirements of the fleets. The fleets had to be provisioned on a scale massive by comparison with former times. ${ }^{54}$ The medieval state had been capable of nothing more than the blood sanctions. The galley sanction was probably not a humanitarian advance, but an administrative feat it surely was.

The galley fleets declined rapidly in the eighteenth century as refinements in sailing ships overcame the former advantages of the galleys. But although "galleys lost naval usefulness, their value as prisons remained."

Proceedings to punish vagabonds, says Damhouder, are "summary and without formal judgment . . . ." Damhouder, ch. 151, at $204^{\mathrm{v}}$. The high evidentiary standards of the Roman-canon law of proof did not apply: capital sanctions were not in question, and vagabondage was a status crime that did not necessarily raise issues turning on proof of conduct. Vagabonds were considered as outsiders, and the community that felt threatened by vagabonds saw little reason to extend to them the safeguards of the regular criminal law, which were meant for citizens. It is possible that the galley sentence developed first against vagabonds, and was then extended to the ordinary criminal law when experience familiarized the authorities with its utility. (For a parallel in the development of inquisitorial criminal procedure in medieval Germany, see Langbein, supra note 7, at 145-51.)

Of course, the use of the galley sentence against vagabonds had a dual aspect: it put the vagabond out of harm's way, and it made his labor available for the navy. The sources suggest that, depending upon the circumstances, one or the other motive might predominate in a particular wave of vagabond repression. When it was the latter, the Continental authorities rounding up vagabonds for the galleys resemble the English of the day impressing sailors, with the difference that the Europeans were casting a wider net. See 3 Colbert, supra note 38 , pt. 1 , at 502 ; cf. Bamford, supra note $2 \hat{3}$, at $180-81$; Masson, supra note 24 , at $263,271-73$; R. G. Usher, Royal Navy Impressment during the American Revolution, 37 Mississippi Valley Historical Review 673 (1951).

52 Schnapper, supra note 8 , at 33 ; Frauenstädt, supra note 22 , at 523-24. It would therefore be surprising if Thompson were correct in his wholly undocumented assumption that the Spanish galleys "probably contained the great majority of serious offenders convicted in Spain, for commutation to galley service was the likely punishment for even the most heinous of crimes." Thompson, supra note 27, at 246. Compare Henry Kamen, Galley Service and Crime in Sixteenth-Century Spain, 22 Economic History Review (2d ser.) 304 (1969), criticizing Thompson for assuming that figures for galley convicts can be treated as indexes of crime.

53 See the account in Bamford, supra note 23, at 191ff.; cf. von Maasburg, supra note 40 , at $8-10$.

54 Bamford, supra note 23 , at $68 \mathrm{ff}$.

55 Bamford, The Procurement of Oarsmen for French Galleys: 1660-1748, 65 American Historical Review 31, 47 (1959); cf. 2 Bohne, supra note 14, at 318. 
the galleys became "essentially prison hulks for the accommodation of convicts who slept aboard, and usually worked ashore by day."58 When the supply of Austrian convicts began to exceed the demands of the Neapolitan fleet, the emperor ordered in 1728 that most convicts be diverted to work in the mines of Hungary or elsewhere. ${ }^{57}$

Throughout its history the galley system had many of the characteristics which would later be associated with the workhouse and the prison. The critical factor was the seasonal constraint upon the galleys' naval operations. In France, for example, "galleys normally went to sea only during the spring or summer of the year, for a campaign of two or three months at most; during the remainder of the year they were tied up in port (except for irregular forays near Marseilles to exercise or train their oarsmen), and the rowing force was employed ashore." 58 Bamford's recent book gives a fascinating account of the way galley service was extended into more general penal servitude. Although each galley convict received a daily ration of food, "the fare would not satisfy an able-bodied man," which "encouraged oarsmen to employ their extra time and energy earning money for supplementary food." ${ }^{\text {69 }}$ A remarkable variety of employment was found for the convicts. Some worked in "tiny shops . . . along the wharves adjacent to the galley anchorage; others labored daily ... on the galley itself at some trade or handiwork. Some worked at widely scattered places around Marseilles. Others left the galley daily at dawn with [guards] accompanying them for regular or occasional work in the metropolis. Another group left the galleys to work in the naval arsenal itself." 60 In the eighteenth century as the galley fleet declined, the convicts were used largely on construction work in the port cities or in manufactories (bagnes) indistinguishable from the prison workhouses of the North. ${ }^{61}$

\section{THE WORKHOUSE}

In the second half of the sixteenth century the institution of the workhouse was developed. Like the galley sentence, "the great novelty" 62 in criminal sanctions of the first half of the sixteenth century, the workhouse also arose to serve social purposes somewhat removed from the ordinary criminal law. It was a response to "the problem of poverty and vagrancy

s6 Bamford, supra note 55, at 47.

57 Von Maasburg, supra note 40, at 10-11.

58 Bamford, supra note 23 , at 27.

59 Id. at 203.

60 Id. at $225-26$.

61 Id. at 234-45, 276-77, 282; cf. 1 Jousse, supra note 8, at 48-50, 62.

62 Schnapper, supra note 8 , at 33 . 
[that] had reached an acuteness probably never before encountered.",63 Nevertheless, the workhouse like the galleys helped bring about a lasting alteration in the system of punishing serious crime. The modern sanction of imprisonment for serious crime traces back to the workhouse for the poor more than to any other source.

The galley sentence was limited to the Mediterranean states and their allies; because the English navy did not have a galley fleet, the galley sentence could not become a feature of English criminal law. ${ }^{64}$ Vagabondage, however, was a European-wide phenomenon, perhaps of particular intensity in England, and it was the English who devised the workhouse.

Throughout the sixteenth century "the position of the poorer classes" 65 was deteriorating and their numbers increasing. By the second half of the century, when Europe was "too densely populated for its resources and no longer riding a wave of economic growth, ... the trend was toward the pauperization of considerable masses of people in desperate need of daily bread."66 The causes were several. Because the European states had become "strong enough to preserve order and to control the power of the great lords," ${ }^{67}$ the feudal private armies were being disbanded as power "passed from the leaders of men to the holders of wealth." ${ }^{178}$ Contemporaries all over Europe recorded that former retainers and soldiers were turning to begging and pillaging. ${ }^{69}$ In the cities the growth of manufacturing created a workforce more exposed to destitution during the low points of the business cycle. ${ }^{70}$ In England the numbers of this nascent urban proletariat may have been swelled by "agricultural laborers and small yeomen"?1 displaced in the enclosure movement. Simultaneously, the influx of bullion "from the New World caused a general rise of prices. Food and clothing and rents rose more quickly than wages, so that the poor could obtain fewer of the necessities of life."72 Finally, "[t] he agencies for giving aid to the poor were themselves in a process of transformation."73 The dissolution of the English monasteries under Henry VIII was unique in rapidity and extent, but elsewhere in

63 Sellin, supra note 30 , at 9.

64 But see infra p. 55.

65 E. M. Leonard, The Early History of English Poor Relief 11 (1900).

${ }^{66} 2$ Fernand Braudel, The Mediterranean and the Mediterranean World in the Age of Philip II, at 743 (S. Reynolds, transl.) (1973).

67 Leonard, supra note 65 , at 14.

68 Id. at 15.

${ }^{60} \mathrm{Id}$. at $15 ; 12$ Isambert et al., supra note 47 , at $216,218-21$; Dạmouder, ch. 151, at $205^{\mathrm{v}}$.

70 Leonard, supra note 65, at 15-16; Sellin, supra note 30 , at 9.

71 Leonard, supra note 65 , at 17.

72 Id. at 16; Sellin, supra note 30, at 9-10.

${ }^{73}$ Sellin, supra note 30 , at 10. 
Europe those "charitable foundations, hospitals, and monasteries, which had reached their greatest development during the preceding two or three centuries under the aegis of the Church, were being dissolved or had deteriorated." 74 What poor relief there was seemed ill-organized and counterproductive-so "indiscriminate [that it] did nearly as much to increase beggars as to relieve them."75

Although contemporaries applied the term "vagabond" to some distinguishable types, there was a fairly consistent core notion. The vagabond was poor, meaning not self-supporting; and he was usually an outsider to the community that called him vagabond, a wanderer from someplace else. Vagabondage tended to be an urban phenomenon. Throughout history surplus population has gravitated to the cities in search of better opportunities than afforded by the land. The anonymity of the cities also made it more difficult for the authorities to detect and control vagabonds' movements. It thus seems no accident that the workhouse movement originated in London, Norwich, Amsterdam, Antwerp, Paris and the cities of the German Hansa. ${ }^{76}$

Within the vagabond stream were several different elements. "The first problem ... is to know who the vagrant actually was, to define his status. For vagrant and vagabond were emotive, elastic terms."77 There were the hopeless, those incapable of work by reason of handicap. Second, there were those capable of work but resisting-the "sturdy beggars" and "common soldiers" whose presence was felt to be so disturbing. Third, some laborers temporarily unemployed were reckoned among the vagabonds, people who wandered occasionally because their permanent work was seasonal or fluctuated with the business cycle. ${ }^{78}$ Finally, contemporaries were quick to lump

74 Id. Compare Brian Tierney, Medieval Poor Law: A Sketch of Canonical Theory and Its Application in England 80ff, 109ff (1959).

$7^{5}$ Leonard, supra note 65 , at 18 .

78 Infra pp. 47-51.

77 Paul A. Slack, Vagrants and Vagrancy in England 1598-1664, 27 Economic History Review (2d ser.) 360, 362 (1974) ; cf. A. L. Beier, Vagrants and the Social Order in Elizabethan England, Past \& Present (No. 64) 3 (Aug. 1974).

${ }^{78}$ Laslett thinks "that at all times before the beginnings of industrialization a good half of all those living were judged by their contemporaries to be poor . . . ." Peter Laslett, The World We Have Lost 47 (2d ed. 1973). Still others, artisans and craftsmen, "were in poverty at certain times of their lives, or in bad seasons, or for some weeks even in good seasons, but not perpetually dependant in the way that laborers, cottagers, paupers and the common soldiery were." Id. at 45 n.40. Hence:

Begging was universal, as it is today in some of the countries of Asia . . . Men sometimes took fright at [the] numbers, especially in Tudor times, and the savage laws against sturdy vagabonds became notorious in the textbooks. . . Yet crowds of destitute people were not typical of poverty in the old world in quite the way that queues of unemployed are typical of industrial poverty. The trouble then, as we have hinted, was not so much unemployment, as under-employment, as it is now called, and once more the comparison is with the countries of Asia in our own century.

Id. at $32-33$. 
with the vagabonds an element of professional petty criminals-prostitutes, gamblers, petty thieves, and the like. ${ }^{79}$ There was a strong current of preventive criminal law in the regulation of vagabondage, a sense "that vagrants and bandits were brothers in hardship and might change places."80

The total social response to the problem of pauperism and vagabondage ranged far beyond the development of the workhouse. There were efforts to induce almsgiving and other charity, to generate tax revenue for poor relief, to restrict movement off the land, to control the price of food, and so forth. ${ }^{81}$ In England "the practice of London and certain other towns was in advance of the regulations of the statutes; the main feature of the period is the municipal organization of poor relief."82 Bridewell, the former royal palace in London whose name became a generic term for later English houses of correction, appears to have been converted to the purpose by the $1550 \mathrm{~s}^{83}$ The Bridewell in Norwich was operating in $1565 .^{84}$ Both cities instituted relatively benign schemes of public relief for the resident poor who could not work or who were in temporary distress, ${ }^{85}$ and both were alert to rid themselves of those recent immigrant poor whose place of settlement was identifiable. ${ }^{86}$ To the Bridewells were sent the "sturdy beggars" 87 and "disordered" persons, ${ }^{88}$ especially the young, and they were compelled to work for their sustenance. In Norwich the order of 1571 read: "The men to grind malt and other works, and the women to use their handedede [sic] and, except they work, not to eat." 89

79 Damhouder, ch. 151, at 205 .

802 Braudel, supra note 66 , at 741 .

81 See generally Leonard, supra note 65 ; Sellin, supra note 30 ; Laslett, supra note 78; Sidney \& Beatrice Webb, English Poor Law History: The Old Poor Law (1927); F. R. Salter, ed., Some Early Tracts on Poor Relief (1926); W. K. Jordan, Philanthropy in England: 1480-1660 (1959).

82 Leonard, supra note 65 , at 62 .

${ }^{83}$ Id. at $35-39$; 1 E. G. O'Donoghue, Bridewell Hospital: Palace, Prison, Schools 193ff. (1923, 1929). See the proposal for the Bridewell workhouse of 1552 in $2 \mathrm{R}$. $H$. Tawney and Eileen Power, Tudor Economic Documents 306ff. (1924), taken from Thomas Bowen, Extracts from the Records and Court Books of Bridewell Hospital (London, 1798).

84 Leonard, supra note 65 , at 101 ; see id. at 110-14 for other English municipal houses of correction built before 1597 ; cf. S. A. Peyton, The Houses of Correction at Maidstone and Westminster, 42 English Historical Review 251 (1927). The statute of 18 Eliz. c. 3, $\$$ 4-6 (1576) ("An Act for the Setting of the Poor on Work, and for the Avoiding of Idleness") prescribed workhouses for every city, town, and county. For an order of the Suffolk court of quarter sessions regulating their workhouse in 1589 , see C. J. RibtonTurner, A History of Vagrants and Vagrancy and Beggars and Begging 116-19 (London, 1887).

85 Leonard, supra note 65 , at $95-98,101-07$.

$86 \mathrm{Id}$. at $98,107$.

87 Id. at 99 , quoting the London order.

88 Id. at 313 , quoting the Norwich order.

89 Id. at 312 . 
Unlike the galley sentence, the workhouse system was not wholly exploitative. The reformative policy of modern penology was present from the outset. The London order of 1579 prescribed: ${ }^{80}$

Such youth, and other as are able to labor and may have work and shall be found idle shall have some manner of correction by the parents, or otherwise as shall be thought good in the parish. And if they will not amend, they shall be sent to Bridewell to be reasonably corrected there.

The workhouse would introduce the inmate to the regimen of honest labor, it would train him in a working skill, and it would reform his character through discipline and moral instruction. Thus equipped, he could be released, no longer a burden to his society. The workhouse would have reformed him.

The workhouse system that was instituted in Amsterdam in the 1590s is the subject of important studies by von Hippel ${ }^{91}$ and Sellin, ${ }^{92}$ work of a sort which has not been done on the English Bridewells. ${ }^{93}$ There were close trade connections between the Netherlands and England, especially Norwich and London. ${ }^{94}$ It is widely supposed that the Amsterdam workhouses were set up in direct imitation of the English. ${ }^{95}$ Another possibility is that the Bridewells served as the inspiration without being a detailed model: "once the idea of using labor and religious instruction as instruments of penal treatment arose, the translation of this idea into practice did not permit any great variety of means."96

From the outset the Amsterdam workhouse (tuchthuis) combined beggars and vagrants with petty criminals, a feature that was to become characteristic of English and German workhouses in the seventeenth century. ${ }^{97}$

Jan Van Hout, whose description of the [first Amsterdam] house [dating from 1597 ] is the earliest known, reported that among the inmates were vagrants without visible means of support, persons sentenced to terms of imprisonment by the magistrates; persons who had been publicly branded or whipped and then committed, and persons committed on petition by friends or relatives because of a dissolute or

90 Id. at 99.

91 Robert von Hippel, Beiträge zur Geschichte der Freiheitsstrafe, 18 Zeitschrift für die gesamte Strafrechtswissenschaft 419, 437ff.; 608 (1898).

92 Sellin, supra note 30.

98 The work by O'Donoghue, supra note 83 , is amateurish. For a recent bibliography collecting related economic history see John Pound, Poverty and Vagrancy in Tudor England (1971) 113-17.

94 Sellin, supra note 30 , at $20-21$.

95 E.g., Schmidt, supra note 20 , at 188 ; see Sellin, supra note 30 , at 21 and sources cited id. at $21 \mathrm{nn} .29-30$. Compare von Hippel, supra note 91, at 648-49.

96 Sellin, supra note 30 , at 21-22.

97 Id. at 41-43 (footnotes omitted). 
irregular life. The professional beggars furnished a sizable contingent. . . The house was used also to punish runaway apprentices. . . . The aim was in many instances to provide an opportunity to learn a trade. . . The terms of the sentences were usually definite in length and were from a few days to many years. While as the time went by ordinances were passed specifying the length of the imprisonment for certain offenses, most sentences could be imposed "at the discretion of the magistrates," permitting a certain amount of individualized punishment.

Once the workhouse was devised for reforming the poor and the wayward, extending it to petty criminals was a small and almost obvious step. Imprisonment at forced labor commended itself as a via media between existing sanctions that were either too harsh for petty crime or else ineffectual. The blood sanctions seemed disproportionately severe, especially for youthful offenders. ${ }^{98}$ On the other hand, banishment ${ }^{99}$ and the lesser corporal punishments seemed inadequate. Banishment merely produced an "exchange" of such offenders "among the individual states . . . ."100 Petty offenders could seldom afford money fines. For such reasons, as noted earlier, the use of simple imprisonment had been growing in the later Middle Ages for some petty offenses. ${ }^{101}$

The workhouse offered two significant advantages over prior sanctions for petty crime. Because it was reformative, it meant to correct as well as to punish. The reformed man would emerge skilled for and reconciled to work. Second, because the workhouse was in fact a small manufactory, it might recover its costs from the labor of its inmates. This form of imprisonment would not burden the perpetually inadequate public revenues of the time. In Norwich the men were "to grind malt;"102 in London some "twenty-five occupations were practised in Bridewell. Amongst these were such trades as the making of gloves, silk lace, pins, bays, felts and tennis balls . . ."103

98 Id. at 18-19.

99 Banishment was often coupled with branding in Europe, in order that exiles who returned could be identified and executed. (It was a capital offense to return in violation of a decree of banishment. See von Maasburg, supra note 40, at 4-7 \& nn.4, 7; cf. Stroobant, supra note 31, at 29.) Sellin, supra note 30 , at 15 n.10, quotes the famous Swedish Judges' Rules of Olavus Petri, lamenting that "those who have stolen . . . stand on the scafford, lose their ears and are banished from the community; if such persons go to other lands where no one knows them and wish to reform and conduct themselves well, they are never trusted. The punishment is a hindrance to him who is punished and he becomes desperate and worse than before. It might have been better for him to lose his life immediately." See generally Gerhard Schmidt, Die Richterregeln des Olavus Petri (1966).

100 Eberhard Schmidt, Entwicklung und Vollzug der Freiheitsstrafe in BrandenburgPreussen bis zum Ausgang des 18. Jahrhunderts 3 (1915).

101 Supra p. 39.

102 Supra p. 47.

103 Leonard, supra note 65 , at 100 . 
The Amsterdam workhouses began with spinning and weaving. When the Dutch weaving industry declined, the women's house turned to the sewing of linen goods and the knitting of nets while the men's house was put to grinding logs into chips from which pigment could be extracted. ${ }^{104}$ "The system of labor used would in modern terminology be called a contract system. The users of the rasped [i.e., ground] wood purchased it from the [workhouse] under contracts approved by the burgomasters." 105 It is a significant indication of the economic potential of the workhouse that inmates were paid in money for production above the minimum required of them in return for their daily keep. "This money constituted a small fund given to the prisoner on his discharge."108

The workhouse satisfied diverse concerns, humanitarian ${ }^{107}$ and practicalfor the relief of the poor, for preventive criminal justice, for reforming wayward youth-while happily paying for itself by extracting the labor of its inmates. It is easy to understand, therefore, why the workhouse system would be adopted widely in the age in which governments developed the administrative capacity to operate such an institution.

The Amsterdam workhouse system in fact exercised enormous influence in northern Europe. Within a few years it acquired such renown in the Netherlands "that near-by cities which had no similar facilities began to request permission to commit to it some of their offenders."108 Numerous Dutch towns built their own workhouses early in the seventeenth century, and in the 1610 s and 1620s the major Belgian cities (Antwerp, Brussels, Ghent) followed suit. ${ }^{109}$ In France, workhouses were being organized in Paris in the 1610 s, then in many other French cities later in the century. ${ }^{110}$ The first German workhouse, in Bremen, was planned after consultation with the Amsterdam authorities and opened in 1613.111 Thereafter Amsterdam and Bremen served as models for the German cities and states. Lübeck's work-

104 Sellin, supra note 30 , at $49,53-54,93$.

105 Id. at 56.

106 Id, at 58. Readers of Bamford's detailed account of the economics of galley service, supra note 23 , esp. $200-249$, will notice remarkable parallels to the system of incentives in the workhouses of the North.

107 Many of the early workhouses were physical outgrowths of former shelters or hospitals for the poor-London (Bridewell), Norwich, Amsterdam, Paris, Lübeck.

108 Sellin, supra note 30 , at 46.

109 Paul Bonenfant, Le problème du paupérisme en Belgique à la fin de l'ancien régime 89-91 (1934); Sellin, supra note 26, at 102-03; Louis Stroobant, Le Rasphuys de Gand: Recherches sur la répression du vagabondage et sur le système pénitentiaire établi en Flandre au XVIIe au XVIIIe siècle, 3 Annales de la société d'histoire et d'archéologie de Gand 191 (1900).

110 Christain Paultre, De la répression de la mendicité et du vagabondage en France sous l'ancien régime $137 \mathrm{ff}$, esp. 160 (1906).

111 Von Hippel, supra note 91, at $608 \mathrm{ff}$. 
house was separate from an earlier shelter for the poor by 1613 . Hamburg's workhouse was long in planning, and was in use by 1622 at the latest. Kassel's was built in 1617, Danzig's in $1629 .{ }^{112}$ Later in the century, after the Thirty Years War, the foundations multiplied: Breslau and Vienna in 1670, Leipzig in 1671, Lüneburg in 1676, Brunswick in 1678, Frankfurt/ Main in 1679, Munich in 1682, Spandau and Magdeburg in 1687, Königsberg in $1691 . .^{113}$ The workhouse spread still more widely in the German states in the eighteenth century. ${ }^{114}$

\section{IMPRISONMENT}

From the middle of the seventeenth century there is evidence that the workhouses for the poor were receiving some inmates who had been convicted of serious crime. By the end of the century specialized institutions were in operation in which serious offenders who would formerly have been subjected to the blood sanctions were confined for long terms at hard labor. The workhouse suggested the prison. This development recorded itself upon the German language. The Dutch tuchthuis became in German the Zuchthaus, a word which lost the meaning of "workhouse" for vagabonds and petty offenders and acquired the modern sense of "prison" or "penitentiary" for serious offenders.

In Bremen in 1648 a young man whose thieving merited death by hanging was, on account of his age and other mitigating factors, sentenced to perpetual imprisonment in irons, then put in the Bremen Zuchthaus to labor for his keep. He was released in 1652. ${ }^{116}$ In Amsterdam one writer reported in 1663 that capital offenders were sometimes not executed, but sent to the tuchthuis for terms from two to 20 years. Another observer in 1696 reported "sentences of the same class of prisoners" from three years to life. ${ }^{116}$ An ordinance of 1639 provided for 10 and 15 year terms in the Danzig Zuchthaus. ${ }^{117}$ In the second half of the century Hamburg was replacing death

112 Id. at $612-47$.

113 Schmidt, supra note 20, at 190.

$114 I d$. For a relatively early perception of the similarity of the workhouse movement in England, the Netherlands and the German states, see 1 Döpler, supra note 8, at 716-25.

Late in the development one German writer complained that the workhouses were proving expensive to build and maintain, and that the profit from convict labor was not enough to offset these costs. 3 Gallus A. C. von Kleinschrod, Systematische Entwicklung der Grundbegriffe und Grundwahrheiten des peinlichen Rechts 51-52 (2d ed., Erlangen, 1799). It has not been possible to locate another work ascribed to this author, Uber die Strafen der öffentlichen Arbeiten (Würzburg, 1789).

115 Von Hippel, supra note 91 , at 610 n.9.

116 Sellin, supra note 30 , at 44.

117 Von Hippel, supra note 91, at 641. 
sentences with long terms of confinement at hard labor. ${ }^{118}$ The Prussian sentence to Festungsarbeit, forced labor on construction projects on the military fortresses and roads, was in use before $1685 .{ }^{119}$ Sentences to forced labor on the highways were used in Nuremberg and Wurtemberg in the seventeenth century, ${ }^{120}$ while at the same time Austria was employing convict labor in the mines and fortresses. ${ }^{121}$

When capital felons were rescued from death for a sentence of hard labor for life, the motive was strictly exploitative. Contemporaries understood that these schemes of lifetime confinement at hard labor were the German equivalents of the galley sentence. ${ }^{122}$

The rationale for the determinate sentences-that is, for terms less than life-was more complex. In Wurtemberg an executive rescript of 1627 instructed the courts to replace the blood sanctions with sentences to forced labor (except for criminals whose crime merited the most extreme death penalties), especially for skilled craftsmen for whose reform there was some hope. ${ }^{123}$ The rescript was obeyed, and offenders who would previously have been banished or maimed or killed were instead put to terms of years or months at forced labor. ${ }^{124}$ In Prussia, Frederick William established the prisons at Spandau and Magdeburg in order to develop a domestic woolen industry with convict labor. ${ }^{125} \mathrm{We}$ see, therefore, motives as diverse as for the workhouse: to reform offenders, ${ }^{126}$ to save the lives of skilled workers who could contribute to the mercantilist state, ${ }^{127}$ to render criminal sanctions more humane, ${ }^{128}$ and to exploit forced labor.

By the middle of the eighteenth century, the combination of the galleys

118 Id.; cf. id. at 630 for Lübeck.

119 Schmidt, supra note 100 , at 13-14; cf. id. at 57-58, 75.

120 Schmidt, supra note 20, at 186; August Hegler, Die praktische Thätigkeit der Juristenfakultäten des 17. und 18. Jahrhunderts 87-88 (Freiburg, 1899).

121 Von Maasburg, supra note 40, at $4 \mathrm{n} .2$. The variety of penal servitude prescribed in the Territorial Courts Ordinance (Landgerichtsordnung) of Dec. 30, 1656, issued by King Ferdinand III for Lower Austria, is summarized in Hugo Hoegal, Freiheitsstrafe und Gefängniswesen in Österreich von der Theresiana bis zur Gegenwart 2 (1916). Criminals could be sent to forced labor on the military settlements along the HungarianTurkish border; put to work on the moats or streets of Vienna or in chain gangs; imprisoned, sometimes on a diet of bread and water; or made to tend the ill in institutions.

1221 Döpler, supra note 8, at 791; cf. Schmidt, supra note 100, at 8; Schmidt, supra note 20 , at 186 .

123 Hegler, supra note 120 , at 88 n.2.

124 Id. at $88 \mathrm{ff}$.

125 Schmidt, supra note 100, at 8-9; Schmidt, supra note 20, at 192.

120 An express concern of Frederick the Great, see Schmidt, supra note 1, at 56-57.

127 Schmidt, supra note 20, at 192-93; Schmidt, supra note 100, at 6-9; Hegler, supra note 120 , at 87 .

128 Id. at 94ff.; Schmidt, supra note 1, at 29-32. 
and the prisons had produced a drastic diminution in the use of the blood sanctions. The maiming sanctions largely disappeared, ${ }^{120}$ and the death penalty declined. Although careful statistical study is thus far lacking, we have enough snippets of evidence to see the pattern. For example, the Nuremberg executioner Franz Schmidt inflicted an average of more than eight capital sentences per year in that city alone from 1573 to $1617 .^{130}$ By contrast, in the 1770 s executions averaged less than 12 per year for the whole of Prussia, ${ }^{131}$ and just over 31 per year for Austria-Bohemia. ${ }^{132}$

\section{TRANSPORTATION}

The workhouse system originated in England, but imprisonment at hard labor as a sanction for serious crime was not systematized there until the middle of the nineteenth century. ${ }^{133}$ Nevertheless, the decline in capital punishment that we have observed on the Continent in the seventeenth and eighteenth centuries also occurred in England, although to a lesser extent. ${ }^{134}$

129 Hegler, supra note 120 , at $87-88 ; 2$ Bohne, supra note 14, at 278-79. Banishment, too, was converted into imprisonment; see, e.g., Schmidt, supra note 1, at 53; Bernard Schnapper, La justice criminelle rendue par le Parlement de Paris sous le règne de François Ier, 52 Revue historique de droit français et étranger 252, 266 (1974).

130 Theodor Hampe, Die Nürnberger Malefizbücher als Quellen der reichstädtischen Sittengeschichte 81 (1927).

131 Schmidt, supra note 1 , at 65.

132 Ernest Kwiatkowski, Die Constitutio Criminalis Theresiana: Ein Beitrag zur Theresianischen Reichs- und Rechtsgeschichte 40-41 (1903). For France see Schnapper, supra note 129 , at $266 \mathrm{ff}$., esp. 270 ; and Schnapper, supra note 8 , at $4-5$. Other recent archive studies (cited $i d$. at 5 n.11) hint that capital punishment was becoming relatively infrequent from the late sixteenth century: Bernadette Boutelet, Etude par sondage de la criminalité dans le bailliage du Pont-de-l'Arche, 12 Annales de Normandie 235, 242-45, 247 n.22 (1962); Jean-Claude Gégot, Etude par sondage de la criminalité dans le bailliage de Falaise, 16 Annales de Normandie 103, 115-18 (1966). See also Noël Laveau, La criminalité à Bordeaux au XVIIe siècle: Etude par sondages, in 8 Receuil de mémoires et travaux publié par la société d'histoire du droit et des institutions des anciens pays de droit écrit 85, 99-103 (1971). Compare for Tuscany Salmonowicz, supra note 9, at 176: "in practice, already in the years before the penal reform of 1786, the death penalty came to be not much executed in the territory ...."

Further archive study is much to be desired, but it is hardly likely to contradict the conclusion of Hegler, supra note 120, at 84-85: "The slow, fundamental transformation of the system of punishments ... of the [Carolina] . . belongs among the most remarkable events in the development of criminal law in the seventeenth and eighteenth centuries."

183 See generally R. S. E. Hinde, The British Penal System: 1773-1950 (1951); H. B. Simpson, Penal Servitude: Its Past and Its Future, 15 L.Q. Rev. 33 (1899).

134 The eighteenth-century Continental writers whose esteem for English criminal procedure was expressed in the campaigns to abolish judicial torture and to introduce the jury system in Europe were not admirers of English substantive criminal law. On the notorious severity of the English criminal statutes, see generally 1 Radzinowicz, supra note 8 ; on the disdain of the philosophes, see 1 id. at $719 \mathrm{ff}$.; Maestro, supra note 3 , at $128 \mathrm{ff}$. 
As a base point, Stephen's suggestion ${ }^{135}$ that executions were running at around 800 per year in England in Elizabeth's last years looks quite reasonable in the light of the evidence. ${ }^{136}$ By contrast, in the year 1805 there were 68 executions. ${ }^{\mathbf{1 3 7}}$ This indicates a decline of more than 90 per cent over the two centuries. Building on Jeaffreson's computations for the seventeenth century, Radzinowicz shows the following decline in executions for Middlesex and London: during the years 1607-1616, 140 executions per year; during the reign of Charles I, 90 per year; during the Commonwealth, 85 per year; during 1749-1758, 36.5 per year; during 1790-1799, 22 per year; and during $1800-1810,12.3$ per year. ${ }^{138}$

As on the Continent, the decline in England's "penal death rate"139 came about because of the development of an alternative to the blood sanctions: transportation of convicts for terms of labor as indentured servants in the overseas colonies. Transportation of felons began as a trickle in the years 1615-1660, became substantial in the period 1660-1700, and expanded greatly after 1717 .

English law was notorious for prescribing the death penalty for a vast range of offenses as slight as the theft of goods valued at twelve pence. Transportation was by no means the only mechanism for avoiding the imposition of the death penalty. Benefit of clergy permitted many first offenders to escape with their lives after being whipped and branded. Sympathetic juries might acquit the guilty or undervalue stolen goods in order to convict culprits of noncapital petty larceny. Royal pardons were surprisingly frequent. ${ }^{140}$ However, it was transportation that gave England a via media

136 1 Stephen, supra note 8 , at 468 .

138 The evidence thus far brought to light is very thin. "In 1596 Edward Hext, a Somersetshire Justice, wrote a letter to one of the members of the Privy Council .... He encloses in it the calendar of the Somerset assizes for that year, showing that forty felons had been executed ...."Frank Aydelotte, Elizabethan Rogues and Vagabonds 73 (1913); see id. at 167-73 for the text of Hext's letter. Cockburn prints figures for Devonshire for 28 years over a 40 year period (1598-1639) that average out to 22.1 executions per year. J. S. Cockburn, A History of English Assizes: 1558-1714, at 94-96 (1972). Stephen was estimating an average 20 executions per year in 40 counties.

1371 Radzinowicz, supra note 8 , at $160 \mathrm{n} .52$.

1381 id. at 141-42. Jeaffreson's seventeenth-century data is from Middlesex alone; he arbitrarily doubled his figures on the assumption, endorsed by Radzinowicz, that the incidence of crime and of punishment was at least as high in the city as in the environs of Middlesex. 1 id. at 141, citing 2 J. C. Jeaffreson, Middlesex County Records xvii-xxi (London, 1886-1892); 3 id. at xvii-xxii.

1393 id. at $\mathrm{xx}$.

1401 Radzinowicz, supra note 8, at 91ff.; 1 Stephen, supra note 8, at 459-71; Abbot E. Smith, The Transportation of Convicts to the American Colonies in the Seventeenth Century, 39 American Historical Review 232, 248 (1934): "no accurate idea of the criminal processes of the seventeenth century can be gained without a study of the system of pardons." 
between the blood sanctions and the petty sanctions, comparable to the French galley sentence or the Austrian and Prussian Festungsstrafe.

Curiously, transportation can be traced to a stillborn attempt to introduce the galley sentence in England. Near the end of the sixteenth century plans seem to have been underway to create an English galley fleet. A statute of 1597 against vagabonds, ${ }^{141}$ one of a group of statutes that formed "the great Elizabethan code"142 of that year for dealing with the poor, authorizes the courts of quarter sessions either to banish certain incorrigible vagabonds or to send them to the galleys. This provision probably did not come into use, but there is evidence from Devonshire and elsewhere ${ }^{143}$ that some convicted felons were reprieved for galley service, whatever that may have meant. Although England did not in fact construct a galley fleet, the prospect of doing so was sufficiently imminent in 1602 to lead Elizabeth to issue a commission to a group of privy councillors and judges, authorizing them "to reprieve and stay from Execution [felons] of strong and able Bodies to serve in Galleys ...."144 This commission became the model for James' commission of 1615 to the Privy Council that first authorized the transportation of felons "who for strength of body or other abilities shall be thought fit to be employed in foreign discoveries or other services beyond the seas."145

14139 Eliz. c. 4 (1597).

142 Jordan, supra note 81 , at 91 .

143 A. H. A. Hamilton, Quarter Sessions from Queen Elizabeth to Queen Anne 31 (London, 1878); Cockburn, supra note 136, at 129. See also a record of letters issued by the Privy Council on June 19,1602 "to all the Justices of Assize . . . for the reprieving of such felons as shall be condemned in their several Circuits to serve in the galleys (if they be not condemned for rape, burglary or other notorious offenses) . . ."32 Acts of the Privy Council of England 489 (J. R. Dasent, ed.) (1907). The second paragraph of the document restates the exclusion "that none shall be sent to the galleys that are condemned for murder, rape or burglary, \&c." Id. The order probably contemplated petty thieves rather than capital convicts, since it conditioned the granting of reprieves on the convicts' "friends [giving] 3 pounds by the year towards their maintenance in the galleys if they be able, or otherwise that the country [i.e., the locality] be moved to contribute so much because by this means they shall be freed from such unprofitable members that would do more mischief to the country than so much money would make good ...."Id. Quaere whether the word "galley" was being used metaphorically for other naval vessels.

There is an even earlier source foreshadowing these turn-of-the-century stirrings. In April 1586 Secretary of State Francis Walsingham wrote to Thomas Egerton, then Solicitor General, instructing him to arrange for reprieving convicts from execution for labor on the galleys. The letter says that one galley "is already built, and more are meant to be built . ..." The Egerton Papers 116 (J. P. Collier, ed.) (Camden Society, London, 1840), cited by Cockburn, supra note 136, at 129.

144 Printed in 7 Thomas Rymer, Foedera, conventiones, literae, et cujuscunque generis acta publica inter reges angliae, pt. 2, at 36 (3d ed., The Hague, 1742). See Daines Barrington, Observations on the More Ancient Statutes 93 n.c. (4th ed., London, 1775).

145 Partially transcribed in Abbot E. Smith, Colonists in Bondage: White Servitude and Convict Labor in America: 1607-1776, at 92-93 (1947). 
Both commissions pertained to persons convicted of "robbery or felony," but excluded the especially heinous offenses of "willful murder, rape and burglary." (The 1615 commission also excluded felons convicted of witchcraft.) Both authorized any six of the commissioners to act, and both had a quorum clause requiring that at least two of those exercising the commission be drawn from a more select group including the Lord Chancellor and the Lord Treasurer. Both empowered the commissioners to reprieve felons for any mission and for any length of service. Both provided for enrolling the orders of the commissioners in the Crown Office of King's Bench.

Most revealingly, the preamble of the 1615 commission follows the language of the 1602 commission, while softening and amplifying it considerably. The "severity of our laws" punishing felony with death make it "most requisite [that] some other speedy remedy be added for ease unto our people." In order to temper justice with mercy, the monarch orders that some of the "lesser offenders adjudged by law to die" be punished instead in a manner that will correct them "and yield a profitable service to the Commonwealth in parts abroad ...." We see the familiar congeries of purposes that motivated the workhouse and the prison: to avoid the severity of the blood sanctions, to correct the offender, to exploit his labor.

The mechanics of sparing convicted felons for transportation went through three phases. The first was the procedure of the 1615 commission, which depended on the initiative of the Privy Council to institute reprieves and to arrange with contractors to export the felons to the colonies. In his admirable study ${ }^{146}$ of the seventeenth century transportation system, A. E. Smith discovered a number of relatively minor revisions of this commission over succeeding decades. ${ }^{147} \mathrm{He}$ computes that fewer than 200 convicts were transported in the forty years to 1655 .

In that year there first appeared the device of the conditional pardon. From 1661 to 1700 about 4,500 convicts were sent to the colonies in this way. ${ }^{148}$ The form was a royal pardon, conditioned upon the convict being transported to the colonies for a fixed term, usually of seven years. This procedure eliminated the need to have the busy Privy Council propel the system. The initiative passed to the assize judges and the entrepreneurs: ${ }^{149}$

After a jail delivery or other major assize, the justices sent up to the secretary of state a pardon fully drafted for such of the convicts as they thought worthy of saving from the gallows. If sentence had already been passed on any of them execution was stayed... . This complete document was then signed by the king and

146 Smith, supra note 140, largely incorporated in Smith, supra note 145.

147 Smith, supra note 145 , at $94-95$.

148 Id. at 96.

149 Id. at $96-98$. 
countersigned by the secretary of state ... . The whole process became purely formal, and no case has been found where a pardon so recommended was refused, though the king frequently commanded that additional persons be included. The last step in the proceedings was for the prisoners to appear in open court and "plead their pardons," after which those who had been slated for transportation were available for shipment. ...

Actual shipment of the convicts was performed by merchants trading to the plantations, and it was enjoined in the pardon itself that they should give good security for the safe conveyance of their charges out of England. Arrangements with these merchants were entrusted to the sheriffs, or to the recorder of London, and the merchants made their profit by selling convicts as indentured servants in the colonies. It was thus essentially a private business, with which the colonial authorities had little or no concern.

The transportation system seems to have declined at the end of the seventeenth century. In Maryland and Virginia, the two principal importers, the colonial legislatures passed hostile laws that "cramped the trade,"150 while "the demand for white servants had lessened in the West Indies . . . ."151 During the period 1704-1715 Smith found "negligible" evidence of transportation and some suggestion that men were instead being pardoned for service in the army. ${ }^{\mathbf{1 5 2}}$ (Marlborough's major campaigns in the War of the Spanish Succession ran from 1702 to 1709 ; the Treaty of Utrecht of 1713 ended the war.) Transportation revived somewhat thereafter: in 1715 and 1716 upwards of 100 convicts were pardoned for transportation. ${ }^{153}$

In 1717 the transportation system entered its third phase and acquired for the first time a statutory basis. ${ }^{154}$ Trial courts themselves were empowered to sentence to transportation persons convicted of the property crimes which had theretofore been punishable by whipping and branding for first offenders on account of benefit of clergy. ${ }^{155}$ (Benefit of clergy for such crimes had been extended to women in the seventeenth century and to illiterates in $1707 .{ }^{156}$ ) For nonclergyable offenses the former system of royal pardon on judicial recommendation continued. The 1717 statute empowered the court itself to "convey" the convicts to entrepreneurs "who shall contract" to transport them. The court was authorized to make these arrangements both for offenders whom it sentenced to transportation and for those guilty of nonclergyable offenses who pleaded conditional pardons.

150 Id. at 104.

151 Smith, supra note 140 , at 243.

152 Id.

153 Id. Compare French practice in directing galley convicts into the opposing army for the same war: Bamford, supra note 23, at 258 .

154 Smith, supra note 145 , at 110 ff.

1554 Geo. I c. 11 (1717).

156 See T. F. T. Plucknett, A Concise History of the Common Law 440 (5th ed., 1956). 
The Act of 1717 was taken to overrule the Maryland and Virginia legislation preventing transportation. ${ }^{157}$ Smith estimates that 30,000 felons were transported to the American colonies in the next 60 years, of whom more than 20,000 were sent to Maryland and Virginia, the rest mostly to the Caribbean. ${ }^{158}$ As a result, one calculation for felony convicts in England in the later eighteenth century suggests that only 7.5 per cent were executed, and most of the remainder transported. ${ }^{\mathbf{1 5 0}}$

The American revolutionary war interrupted England's export of convicts in the 1770s. As a stopgap, which in fact lasted until the foundations of the modern prison system in the mid-nineteenth century, the government "decided to moor hulks on the Thames, put convicts in them and work them at hard labor." 160 When it became clear in the 1780s that the American colonies were lost for the purpose, the Australian penal colony at Botany Bay was established. ${ }^{161}$

\section{EUROPE AND ENGLAND}

The transportation system was England's analogue to the Continental galley and prison sanctions, and contemporaries knew it. For example, in a tract $^{162}$ written in 1725 Bernard Mandeville criticized various aspects of the transportation system. Convicts escaped before shipment, he complained, or returned to England prematurely. In the New World they were less an asset than a liability, corrupting the Negro slaves. By contrast, Mandeville pointed out, the French and Spanish "make use of Malefactors in their Galleys," and "the great Cities of [Holland] have all Work-houses for Criminals. At Amsterdam there is one, where Felons are kept constantly employed in rasping of Brasil Wood."103 Hence the author's modest proposal, to send English felons into galley service with the Moroccans in exchange for the captive British sailors now there. ${ }^{164}$

157 Smith, supra note 145 , at 113 .

158 Id. at 117, 119.

There is also considerable evidence of the use of penal servitude in lieu of the former sanctions for serious crime in the colonial legal systems in the seventeenth and eighteenth centuries. See Richard B. Morris, Government and Labor in Early America 345ff. (1946) and sources there cited.

159 Smith, supra. note 145 , at 117 \& n.23, citing an unpublished London University Ph.D. Thesis: Wilfrid Oldham, The Administration of the System of Transportation of British Convicts: 1763-1793, at 35 (1933).

160 A. L. Shaw, Convicts and the Colonies: A Study of Penal Transportation from Great Britain and Ireland to Australia and Other Parts of the British Empire 43 (1966). See also Sidney \& Beatrice Webb, English Prisons under Local Government 43-46 (1922). 161 Shaw, supra note 160, at 48-57.

162 Bernard Mandeville, An Enquiry into the Causes of the Frequent Executions at Tyburn (London, 1725).

163 Id. at 53 (italics original).

164 Id. at $47 \mathrm{ff}$. Mandeville foresaw as the principal drawback to his scheme the concern that some of the repatriated English sailors might have fallen into apostasy during 
With Mandeville's suggestion we may contrast a message from the younger Colbert to a provincial judge issued in 1684, during Louis XIV's sustained effort to build up the French galley fleet: ${ }^{165}$

The king has been informed that you have rendered several sentences to send to the American islands, as a manner of punishment, people who have fallen into disorder. And as this punishment has never been known in France, his majesty commands me to write you that he does not want you to order [it] any more.

Transportation could only have been instituted in France at the expense of the galleys.

The parallels between the European galley and prison schemes and the English transportation system are numerous and striking:

(1) Both sanctions were introduced in the exercise of executive clemency for convicts who would otherwise have been subjected to the blood sanctions. In time, both were incorporated into the ordinary criminal process as sanctions imposed by the courts.

(2) Both represent an administrative feat, in organizing and refining relatively complex schemes to extract convict labor.

(3) Both were used as sanctions for serious crimes, but not the most serious. Transportation was overwhelmingly limited to property crimes, ${ }^{166}$ and we have seen that the worst offenders continued to be executed on the Continent. Nevertheless, the new sanctions achieved a drastic diminution of capital punishment on both sides of the English Channel. ${ }^{167}$

(4) Both served a similar combination of purposes-to moderate the blood sanctions, to eliminate criminals from the society, to exploit convict

captivity. "Amongst our Seafaring Men, the Practice of Piety is very scarce . . . There are not many that are well grounded in the Principles of their Religion, or would be capable of maintaining it against an Adversary of the least Ability; and we are not certain, that under great Temptations, they would remain steadfast to the Christian Faith." Id. at 48-49.

1652 Depping, supra note 38, at 245. The French did experiment with transporting aged and invalid galley convicts. See Bamford, supra note 23, at 255, 260.

166 A. E. Smith, supra note 145, at 107.

167 Considerable differences persisted among nations, of course. We have seen that the British figures were many times the Prussian. A flamboyant French abolitionist tract suggested in 1770 that the penal death rate was higher in France than elsewhere, although the proposition is unsupported:

The Sicilians put their criminals to work in the quarries; the Portuguese employ them in those discoveries that have extended for us the limits of the world; the Russians in populating their deserts; the English in developing their colonies; the Germans make them roll their wheelbarrows [in] galères de terre; the Africans exchange them for goods; are we alone in wringing the life out of them in public, in order to send them [i.e., the rotting corpses] from there to infect our highways? Philopon de la Madeleine, "Discours sur la nécessité et les moyens de supprimer les peines capitales, Lu dans la séance publique tenue par l'Academie des sciences, belleslettres \& arts de Besançon, le 15 décembre 1770," in 4 Bibliothèque philosophique du législateur 63 (J. P. Brissot de Warville, ed.) (Berlin, Paris \& Lyon, 1782). 
labor, to reform offenders. Human life became more valuable in the midseventeenth century. The Europeans had suffered the catastrophic population losses of the Thirty Years War, and the English were trying to populate an empire while fending off the French. ${ }^{168}$

(5) Both paved the way to the present systems of penal servitude. In the eighteenth century French galley convicts and English transportees found themselves confined to hulks in domestic ports, from which they were led forth to daily labor on public works-like their counterparts in the fortresses, mines, and prisons of Austria, Prussia, and the Netherlands.

168 Hegler, supra note 120, at 87; George L. Beer, The Origins of the British Colonial System: $1578-1660$, at $32-52$, esp. 34 (1908). 